\title{
Formulating Economic Policy for 1979 and Beyond: Old Problems and New Constraints
}

\section{KEITH M. CARLSON}

HE Administration recently outlined its economic strateg, for 1979 and 1980, and also addressed some of the longer-term economic problems that will face the United States in the early 1980s. ${ }^{1}$ The major problem confronting the Administration has become familiar - reducing inflation without provoking a recession. This problem has been complicated, however, by recently enacted legislation, the Full Employment and Balanced Growth Act of 1978 (Humphrey-Hawkins) and the Revenue Act of 1978.

The Humphrey-Hawkins Act includes national economic goals for 1983 among its provisions. In particular, the Act calls for

(1) reducing the rate of unemployment to not more than 3 percent for individuals aged twenty and over and 4 percent for individuals aged sixteen and over;

(2) reducing the rate of inflation to not more than 3 percent.

The Act also contains the proviso that policies and programs for reducing the rate of inflation be designed so as not to impede achievement of the goals and timetables specified for the reduction of unemployment.

The responsibility for achieving these goals belongs to the President of the United States. He must submit an economic report and a budget which outline the programs and policies deemed necessary to achieve the goals of the Act.

The Act also indicates a role for monetary policy. The Board of Governors of the Federal Reserve System is required to present to Congress the relationship between its plans and the short-term goals presented in the President's economic report. The Federal Reserve is required only to specify its plans for the coming year, and need pot outline its actions for the longer term through 1983.

The Revenue Act of 1978 imposed an additional set of constraints on the Administration's policymaking

1The Administration's economic plans are contained in two basic documents, the Budget of the United States Covernment for Fiscal Year 1980 and the Economic Report of the President, which also includes the 1979 Annual Report of the Council of Economic Advisers. process. This Act was designed primarily to reduce taxes to stimulate consumer and investment spending and to improve the equity of the tax system. However, the Act also contains a Congressional policy statement about the growth rate of Federal outlays and possible further tax reduction:

... as a matter of national policy the rate of growth in Federal outlays, adjusted for inflation, should not exceed 1 percent per year between fiscal year 1979 and fiscal year 1983; Federal outlays as a percentage of gross national product should decline to below 21 percent in fiscal year $1980,20.5$ percent in fiscal year 1981,20 percent in fiscal year 1982 , and 19.5 percent in fiscal year 1983; and the Federal budget should be balanced in fiscal years 1982 and 1983 .

The President presented the first economic program under the provisions of this new legislation to Congress and the public in January. The details of the program are outlined in the Budget of the United States Government for Fiscal Year 1980 and the Economic Report of the President. The Federal Reserve submitted its report to Congress in a Letter of Transmittal dated February 20, 1979. This article summarizes and evaluates the Administration's economic plan along with the Federal Reserve's statement of intent. The focus is on whether these monetary and fiscal plans are consistent with the achievement of the goals of the Humphrey-Hawkins Act and the Revenue Act of 1978 .

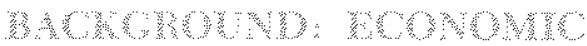

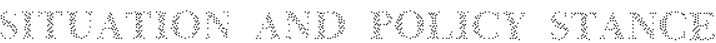

In order to prepare a national economic program, one must consider the current economic situation and the stance of monetary and fiscal policy. In addition, it is helpful to understand how the economic situation evolved in light of past policy developments.

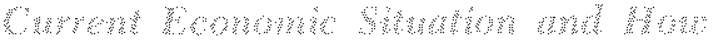

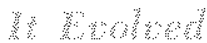

In April 1978, the U.S. economy entered the fourth year of expansion." Strong economic growth and em-

2Economic developments in 1978 are reviewed in the 1979 CEA Report, Chapters 1 and 2. See also Michael E. Trebing, "Economic Developments in 1978," this Review (February 1979), pp. 11-18. 


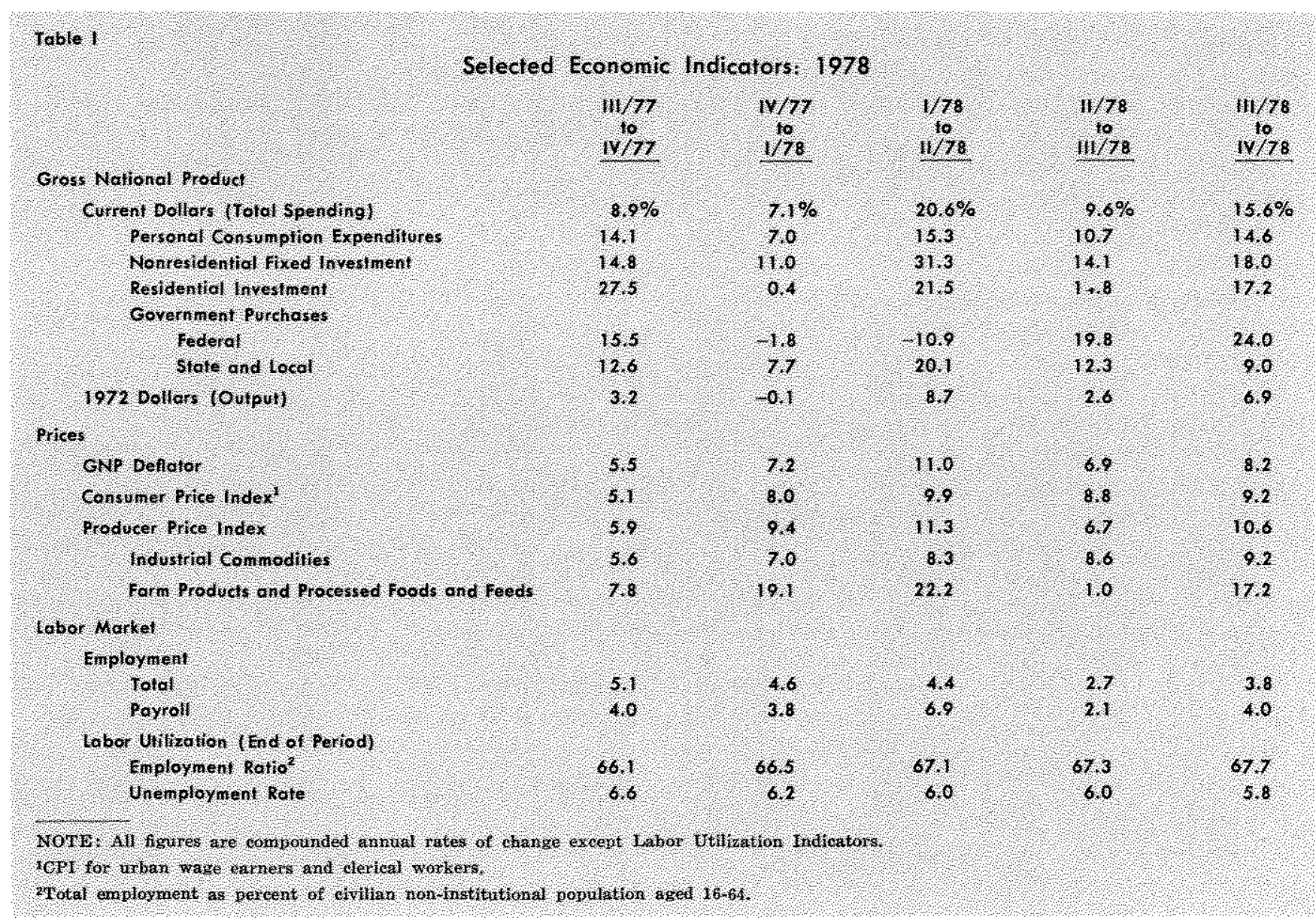

ployment gains were registered in 1978, but the economic record was marred by accelerating inflation.

Total spending rose 11.7 percent in 1978 , up slightly from an 11.0 percent increase in 1977. In the past year, however, the distribution of the year's growth in total spending between output and prices was substantially different than in 1977. Output growth slowed to 4.0 percent after advancing 4.9 percent in 1977. Inflation accelerated to 7.4 percent in 1978 from the 5.9 percent pace in the previous year. Total employment, however, rose 4.2 percent compared to a 3.5 percent increase in 1977 .

Quarter-to-quarter variation in GNP, output, and prices was substantial in 1978 (Table I). Yet, there is little question that the growth of total spending was very strong toward the end of the year. Spending increased at a $\mathbf{1 5 . 6}$ percent annual rate in the fourth quarter which was distributed as a 6.9 percent rate of advance of output and an 8.2 percent rate of inflation.

Accelerating inflation was the most disturbing economic development of 1978 . The sharp rise in prices was not accurately predicted by either the Administration (Table II) or by most private forecasters. Consequently, the Council of Economic Advisers (CEA) devoted considerable space in its 1979 Annual Report to an analysis of the 1978 inflation. ${ }^{3}$ The Council's analysis divides the sources of inflation into two parts - that due to "special factors," and that due to a change in the underlying rate of inflation.

Special factors refer to unusual price movements in particular markets and are generally, but not always,

31979 CEA Report, Chapter 2.

Table I

Administration Forecasts for 1978

\begin{tabular}{|c|c|c|c|}
\hline & \multicolumn{2}{|c|}{ forecost } & \multirow[b]{2}{*}{ Astud } \\
\hline & Joneary 1978 & $101 \times 1978$ & \\
\hline GNP & $110 \%$ & $10 \%$ & $117 \%$ \\
\hline Output & 47 & $41 \mathrm{~s}$ & 40 \\
\hline prices & 61 & 6.5 & 7,4 \\
\hline Unemployment rote & 6.3 & 0.0 & 6.0 \\
\hline
\end{tabular}

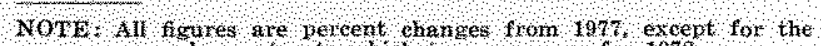
unenployment rate wheh is an aterage for 1978 


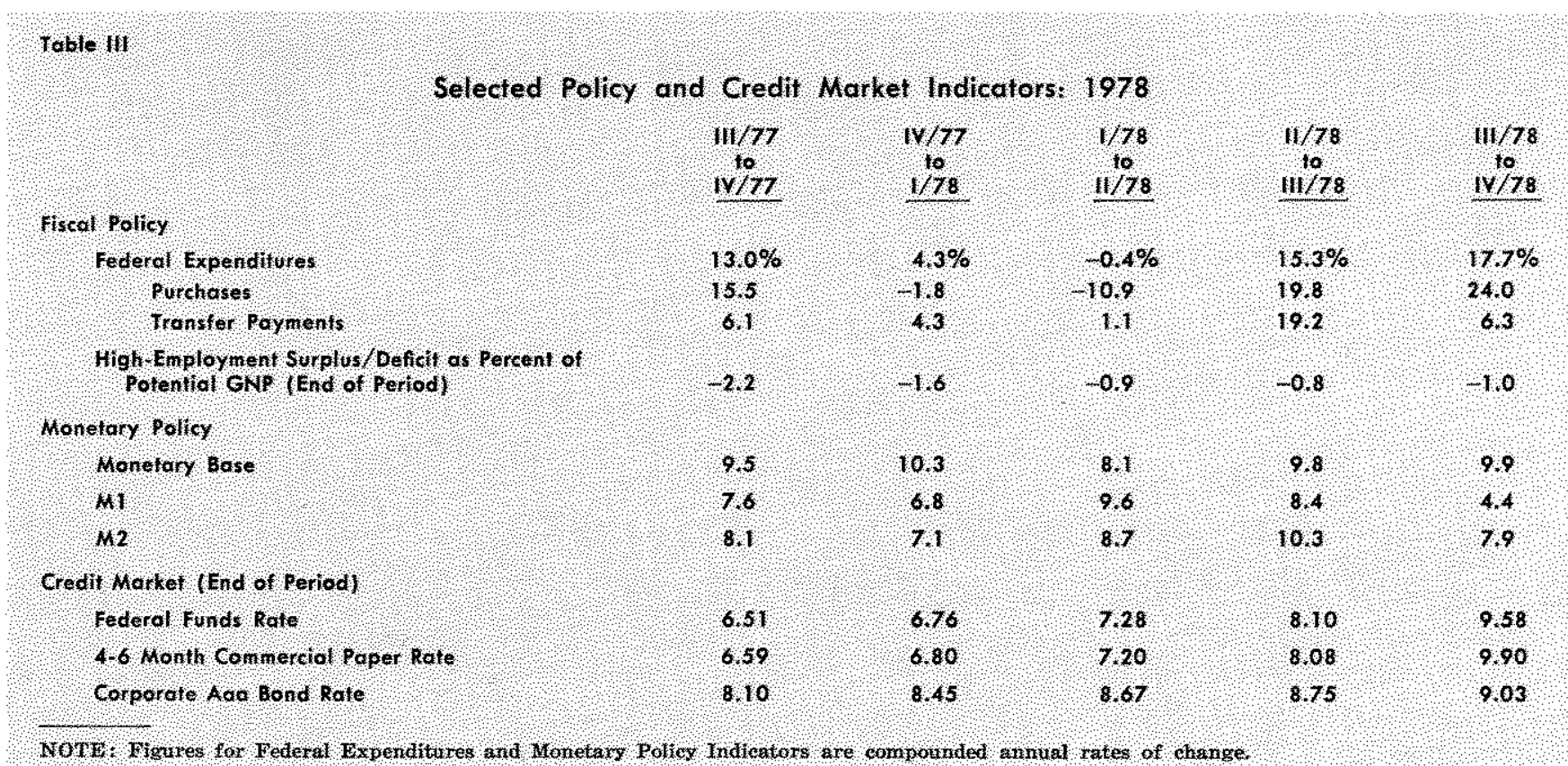

related to unexpected shocks on the supply or production side of the economy. Some of the special factors which had an important influence on inflation in 1978 were food prices, the depreciation of the dollar, and housing costs. The CEA pointed out, though, that these special factors fall short of providing a complete explanation for the acceleration of inflation in 1978.

Most of the acceleration, it contends, was caused by a substantial increase in the "underlying rate of inflation," defined as the rise in prices, excluding food and energy. According to the CEA, changes in the underlying rate of inflation are closely tied to movements in unit labor costs. The rise in unit labor costs in 1978 was "explained" by an acceleration of money wages and a sluggish advance in productivity. Money wages accelerated because excess demand developed in labor markets, as indicated by a rapid decline in unemployment. The demand for labor exceeded labor force growth, which reflected increases on the demand or spending side of the economy. The CEA suggested that the January 1978 increase in the minimum wage also contributed to wage acceleration.

The fundamental development underlying the accelerating inflation in 1978, according to the CEA's analysis, was the slow growth of productivity. For the private nonfarm business sector, the 0.5 percent increase in output per hour in 1978, in conjunction with a 9.3 percent increase in wages, meant that unit labor costs rose 8.7 percent, which placed pressure on

4For a contrasting analysis, see Albert E. Burger, "Is Inflation All Due to Money?" this Review (December 1978), pp. 8-12. profit margins and thereby encouraged price hikes. In comparison, unit labor costs rose 6.7 percent in 1977.

The sluggish pace of productivity in 1978 led the CEA to reassess productivity trends in recent years. This resulted in a downward revision of their estimates of potential GNP from mid-1973 through 1978. According to these revised estimates, the economy has been operating much nearer its potential in recent years than previously had been thought."

\section{Polven stance}

Monetary and fiscal actions are important factors in evaluating past and prospective economic conditions. Both monetary and fiscal policy tend to affect the pace of economic activity with a lag, so their recent trends are important in formulating an economic outlook and in developing policies for the near future.

Although there are various measures of fiscal action, the growth of Federal expenditures is possibly the most meaningful measure of fiscal stimulus or restraint. ${ }^{6}$ An examination of this growth in 1978 (Table III) indicates that fiscal policy became relatively re-

\footnotetext{
5The newly revised CEA series on potential GNP is now quite similar in magnitude to that developed by Robert $\mathrm{H}$. Rasche and John A. Tatom, "Energy Resources and Potential GNP," this Review (June 1977), pp. 10-24.

tLeonall C. Andersen and Jerry L. Jordar, "Monetary and Fiscal Actions: A Test of Their Relative Importance in Economic Stabilization," this Review (Novenber 1968), pp. 11-24.
} 
strictive in the first half of the year but sharply expansionary in the second half.

Monetary policy, on the other hand, was clearly expansionary throughout most of $1978 .{ }^{7}$ This was a continuation of the rapid monetary expansion that began in late 1976 and carried through 1977. Growth rates of $\mathrm{M} 1$ and $\mathrm{M} 2$ were well above their long-term trends until late in the year (Table III). Only then did the growth of these aggregates slow, which indicates that monetary actions were turning restrictive or, at least, less expansionary.

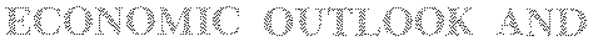

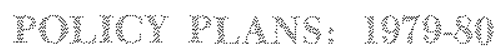

The economic outlook for the next year or two depends primarily on one's assessment of the economy's momentum. The forecast, however, also depends on one's framework of analysis since this framework provides the link between policy actions and economic activity. Policy recommendations will vary depending on whether movements in economic activity are attributable to monetary and fiscal policy or to exogenous forces beyond the control of the policymaker.

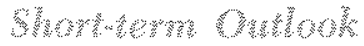

The CEA has forecast a growth in GNP of 9.8 percent from fourth quarter 1978 to fourth quarter 1979 (Table IV) to be distributed as a 2.2 percent advance in output and a 7.4 percent rise in prices. $^{8}$ The Council expects the unemployment rate to rise slightly to 6.2 percent by fourth quarter 1979 .

GNP in 1980 is forecast to rise at the same rate as in $1979-9.8$ percent. The distribution between output and prices is expected to be more favorable, however, with output projected to rise 3.2 percent and inflation to slow to 6.4 percent. Unemployment is predicted to remain at 6.2 percent.

The CEA expects inflation to slow in 1979 for reasons of demand-pull, that is, easing of pressure from the spending side of the economy. Output growth is projected to drop below its long-term trend. This forecast differs markedly from the CEA forecast

7The CEA interpreted monetary actions as restrictive throughout most of the year. See 1979 CEA Report, pp. 28, 47-53.

8Discussion of the outlook is found in the 1979 CEA Report, Chapter 3. A comparison of the CEA's forecast with a con" sensus of private forecasters shows that they are not far apart. The CEA tends to be a bit more optimistic than the consensus, but the differences are not large.

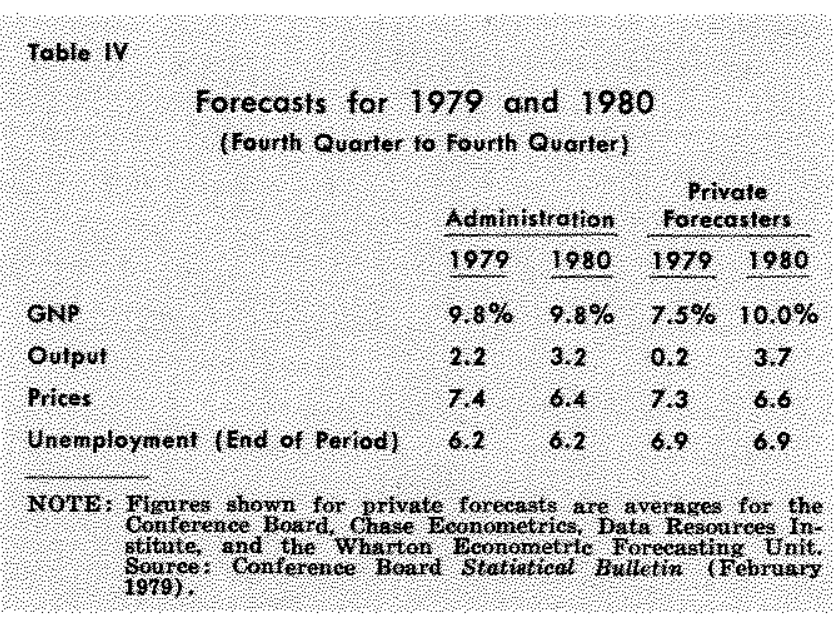

for 1978. Potential GNP is now seen as a con+ straint on the growth of output, and the projected slowing of this growth is viewed as desirable in order to reduce inflation. In early 1978 , potential GNP was estimated to be high enough, relative to the projection of output, for the CEA to consider demand pressures a minor threat to reducing inflation.

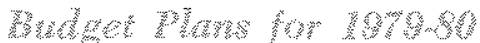

The CEA has indicated that inflation is the No. 1 problem facing the nation's policymakers. Despite the limited role assigned to monetary and fiscal actions in explaining the acceleration of inflation in 1978, the CEA recommends a policy of "measured" monetary and fiscal restraint. ${ }^{9}$ The Administration's budget plan is labeled "austere."10 The basis for this label is that the proposed growth of Federal outlays for fiscal years 1979 through 1982 is less than the projected rate of increase of GNP.

The Administration's proposed budget plans on a quarter-by-quarter basis are shown in Table V. ${ }^{11}$ According to these figures, fiscal restraint, as measured by the growth of expenditures relative to receipts, will not become effective until calendar 1980. Continued stimulus is projected through 1979 .

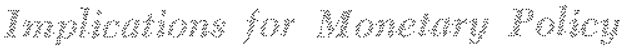

The CEA's discussion of monetary policy in 1979 and 1980 is sketchy. It stresses the importance of monetary restraint, but does not recommend a pre-

OIbid., pp. 79-80, 93-97.

10See The Budget of the United States Government for Fiscal Year 1980, p. 12 .

11For a detailed discussion of the Administration"s budget plan see Charles A. Waite and Joseph C. Wakefield, "Federal Fiscal Programs," Survey of Current Business (February 1979), pp. 21-33. 


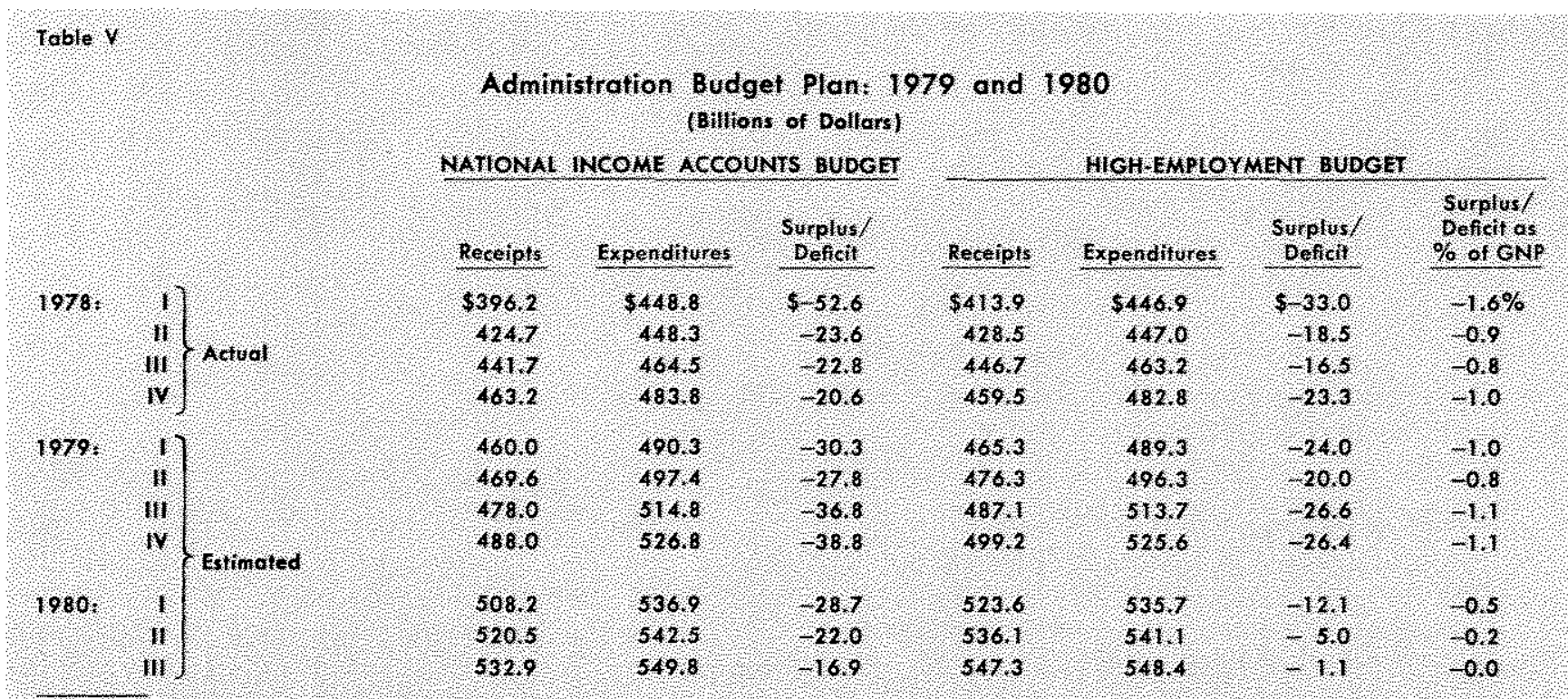

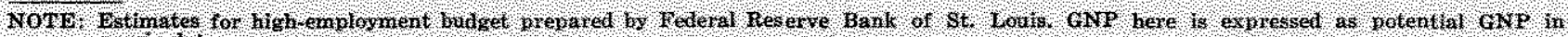
nominal terno,

ferred growth rate for the major monetary aggregates. Given past behavior patterns for M1 velocity, however, the 9.8 percent projected growth for GNP suggests a growth in M1 of between 6 and 7 percent. Considering the effects of automatic transfers, one could interpret the Administration's strategy as a call for about a 3 to 4 percent growth in measured M1. ${ }^{12}$ The 1980 forecast of GNP indicates a continuation of this growth rate.

Under the provisions of the Humphrey-Hawkins Act, the Federal Reserve must outline its strategy in light of the Administration's plan. The Federal Reserve presented its strategy to Congress on February $20{ }^{13}$ In its report, the targets of $1 \frac{1 / 2}{20} 4^{1 / 2}$ percent for M1 growth for the year ending fourth quarter 1979 were deemed consistent with the Administration's short-term goals. This range includes the 3 to 4 percent M1 growth implied by the CEA's GNP forecast, that is, when account is taken of velocity growth and the effects of automatic transfers. The movements of the aggregates since late 1978, however, indicate that this M1 range has not been met thus far in 1979 . Preliminary estimates indicate that M1 declined at a 2.3 percent rate in the first quarter. To achieve the Federal Reserve's target range, M1 growth would have to accelerate to a 2.8 to 6.9 percent rate for the rest of the year.

\footnotetext{
12John A. Tatom and Richard W. Lang, "Automatic Transfers and the Money Supply Process," this Review (February 1979), pp. 2-10.

13" Monetary Policy Report to Congress," Federal Reserve Bulletin (March 1979), pp. 185-200.
}

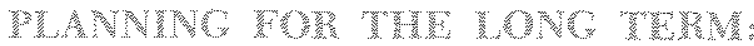

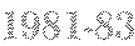

Since 1974, the Administration has presented longterm projections for the economy and the budget along with its short-term forecasts. ${ }^{14}$ These long-term projections were introduced into the economic planning process by the Budget Control Act of 1974 . Effective in 1979, however, the nature of these projections was changed by the enactment of the Humphrey-Hawkins Act. Previous Administrations were simply required to present these projections. Under the Humphrey-Hawkins Act, these projections must now be consistent with the Act's long-term goals for unemployment and inflation.

A further constraint on long-term budget planning was introduced in the Revenue Act of 1978. That Act specified targets for the growth of Federal outlays and their size relative to $\mathrm{GNP}$, and presented a timetable for achieving a balanced Federal budget. These targets, however, are conditional and must be met only if further tax reductions are to be enacted.

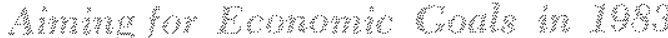

The Humphrey-Hawkins Act of 1978 specifies targets for economic policy in 1983. These targets consist of reducing unemployment to 4 percent of the labor force and lowering the inflation rate (as measured by

\footnotetext{
14For a summary of the long-term projections made in past years, see Keith M. Carlson, "Economic Goals for 198I: A Monetary Analysis," this Review (November 1977), p. 3 .
} 


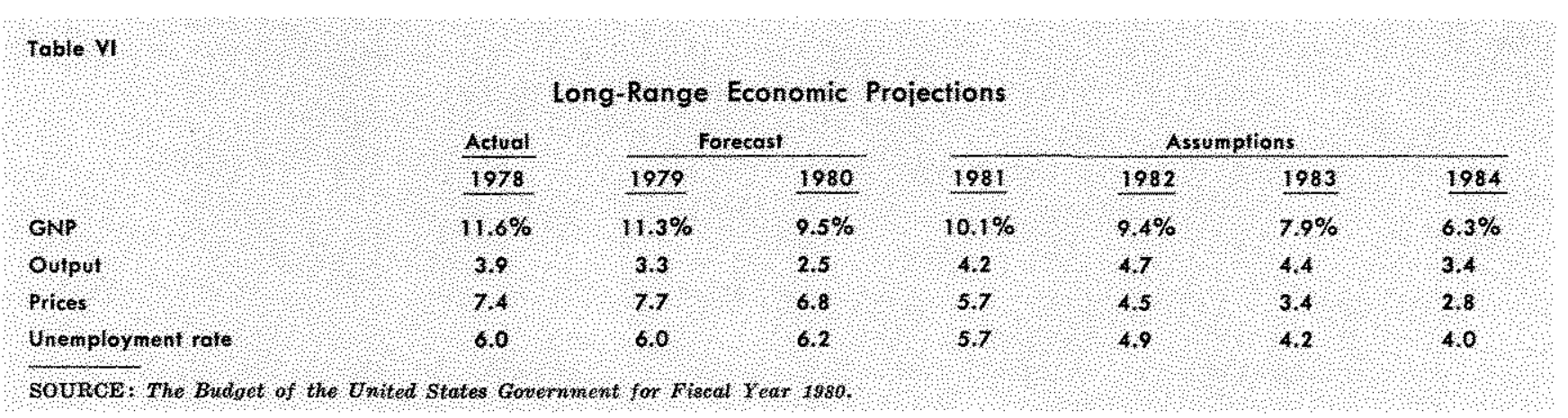

the consumer price index) to 3 percent per annum. The Act does not specify how to achieve these goals, but it does suggest that monetary and fiscal policies be supplemented with manpower policies and wageprice guidelines.

The Budget document details the economic projections through calendar 1984 (Table VI), and presents budget estimates through fiscal 1984. The economic projections for 1981 through 1984 are not presented as forecasts of probable economic conditions. They are, rather, projections that assume progress toward the goals of the Humphrey-Hawkins Act. ${ }^{15}$ Only the budget estimates through 1982 are intended to be budget plans. Projections for 1983 and 1984 are simple extrapolations beyond the planning base. ${ }^{ \pm 6}$ The Administration does not offer a budget plan designed explicitly to achieve the long-run economic goals.

The CEA's 1979 Annual Report discusses long-term goals and some of the factors that will have a bearing on their achievement. ${ }^{17}$ The discussion is general, with no specific recommendations for monetary and fiscal policy for achieving the goals. The CEA focuses its discussion of the Humphrey-Hawkins Act on the feasibility of achieving the inflation and unemploy. ment goals simultaneously. In previous sections of its report, the CEA suggests that a 6 percent unemployment rate indicates a tightness in labor markets which causes wages to accelerate. Consequently, the CEA concedes that the unemployment target cannot be reached by means of monetary and fiscal policies alone, and argues that structural initiatives to improve the functioning of the labor market will also be needed.

The simultaneous achievement of the inflation goal, on the other hand, is discussed within the context of

\footnotetext{
15See the discussion in The Budget, p. 37 .
}

16Ibid., pp. $40-41$.

171979 CEA Report, pp. 106-134. striving to reduce inflation with the help of wageprice guidelines. The CEA does recognize the importance of changing tax policy to encourage investment and thereby step up the growth of potential GNP. Emphasis also is given to the improvement of the social and economic regulatory process so that incentives to produce and invest will not be dampened further. The direct role of monetary expansion in achieving the long-rum inflation goals is not mentioned by the CEA.

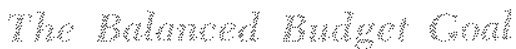

The other major constraint imposed on the Administration is specified in the Revenue Act of 1978. This constraint is spelled out in terms of a timetable for slowing Federal spending as well as balancing the budget by fiscal 1983. Since budget estimates beyond 1982 are only extrapolations, these projections are suggestive at best.

Table VII indicates that long-term budget projections do not fulfill the requirement of the Act. The requirement of a balanced budget by fiscal 1982 is met, but outlays as a percent of GNP are too large in each of the years. The rate of growth of outlays exceeds the rate of inflation by more than 1 percent in every year but 1980 .

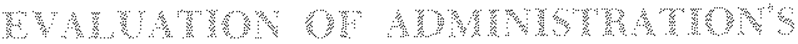

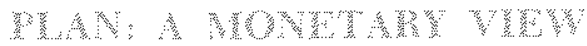

The Administration's economic plan does not consider the implications of alternative growth paths for the monetary aggregates. This is true for both the short-term and the long-term projections. For purposes of comparison, the Administration's plan is analyzed within the context of the St. Louis model. ${ }^{18}$

\footnotetext{
18 The model used here is a slightly modified version of that described in Leonall $C$. Andersen and Keith M. Carlson, "A Monetarist Model for Economic Stabilization," this Review (April 1970), pp. 7-25.
} 


\begin{tabular}{|c|c|c|c|c|c|c|c|}
\hline \multicolumn{8}{|l|}{ Table Yu } \\
\hline & \multirow{2}{*}{$\begin{array}{l}\text { Actual } \\
1978\end{array}$} & \multicolumn{4}{|c|}{ Esfinoles } & \multicolumn{2}{|c|}{ Prolections } \\
\hline & & 1979 & 1980 & 1981 & 1982 & 1983 & 1984 \\
\hline \multicolumn{8}{|l|}{ Recepts } \\
\hline current services & $\$ 4020$ & $\$ 456.0$ & $\$ 5045$ & $\$ 5713$ & $\$ 646,6$ & $\$ 7153$ & $\$ 7778$ \\
\hline Proposed honges & & & -18 & 45 & 6.0 & 30 & 2.4 \\
\hline Budget recepts & 4020 & 456.0 & 5026 & 5768 & 652.6 & 7183 & 780.2 \\
\hline \multicolumn{8}{|l|}{ Outloys } \\
\hline curtent services & 450.8 & 4913 & 5361 & 5778 & 6106 & 6402 & 6671 \\
\hline Boposed changes & & 21 & $-4,5$ & 02 & 4,3 & 54 & 66 \\
\hline Budget oullays & 450.8 & 190.4 & 5316 & 5790 & 6149 & 6456 & 673.7 \\
\hline \multicolumn{8}{|l|}{ Surplus/Defiet } \\
\hline currentservices & 488 & 35, & $\mathbf{3 1 1 6}$ & 605 & 36.0 & 751 & 1107 \\
\hline Proposed dhonges & & -2.0 & 26 & 53 & 18 & -2.4 & 4,4 \\
\hline Budget surplus/defeit & 48.8 & 374 & 290 & 12 & 378 & 72. & 1065 \\
\hline oulloys of $\%$ of GMP & $221 \%$ & $21.6 \%$ & $21, \%$ & $210 \%$ & $20.3 \%$ & $197 \%$ & $19,3 \%$ \\
\hline$\%$ change ho outloys & $11 \%$ & 94 & 77 & 8.7 & 64 & 50 & 44 \\
\hline$\%$ ehange in GNP deflator & 6.8 & 79 & 70 & 5.9 & 4.8 & 0.6 & 29 \\
\hline Bifference & 51 & 13 & 07 & 28 & 1.6 & 14 & 16 \\
\hline
\end{tabular}

The model is used to project the course of intlation and unemployment using the path for nominal GNP contained in the Administration's economic plan. For purposes of the simulation, no impact was factored in for either the wage-price guidelines or for structurally-oriented programs to improve the functioning of the labor market. Table VIII summarizes the results.

The St. Louis model indicates that, since inflation was so rapid in 1978, its momentum will carry through into the early $1980 \mathrm{~s}$, especially if monetary and fiscal policies are stimulative enough to generate GNP advances in the range of 9.5 to 10 percent. Even with sluggish growth in output into 1981, the momentum of inflation is strong enough to more than offset the downward pressures on prices associated with that slow growth.

The inflation projection, along with the GNP path assumed by the Administration, leaves little room for real growth. As a result, unemployment rises steadily. Then, in 1983 and 1984, if GNP growth is reduced before the inflation rate has been lowered to any great extent, output growth will be slowed further. Consequently, unemployment jumps sharply in 1983 and 1984.
The purpose of presenting these simulations is to show that, in the St. Louis model, the Administration's GNP projections are not consistent with a path of steadily declining inflation. Given that this inflation path is unlikely, the paths of output growth and unemployment are also brought into question.

Table VIII presents some alternatives to the GNP path outlined by the Administration. The 4,6 , and 8 percent paths for $\mathrm{M} 1$ correspond to the $\mathrm{M} 1$ measure before the introduction of automatic transfers. Each of these paths was generated from first quarter 1979 as a starting point for M1. According to these alternative simulations of steady money growth, the spirit of the Humphrey-Hawkins Act is most closely met if money growth is kept moderate. Each of the alternatives indicates the difference between short-run and long-run costs and benefits. Policymakers are confronted with the difficult task of choosing between short-term benefits and long-term costs.

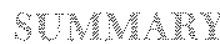

The Administration has developed a multi-faceted economic plan for the nation. The problem confrontm ing the Administration in the short run is quite familiar-how to reduce inflation and unemployment 


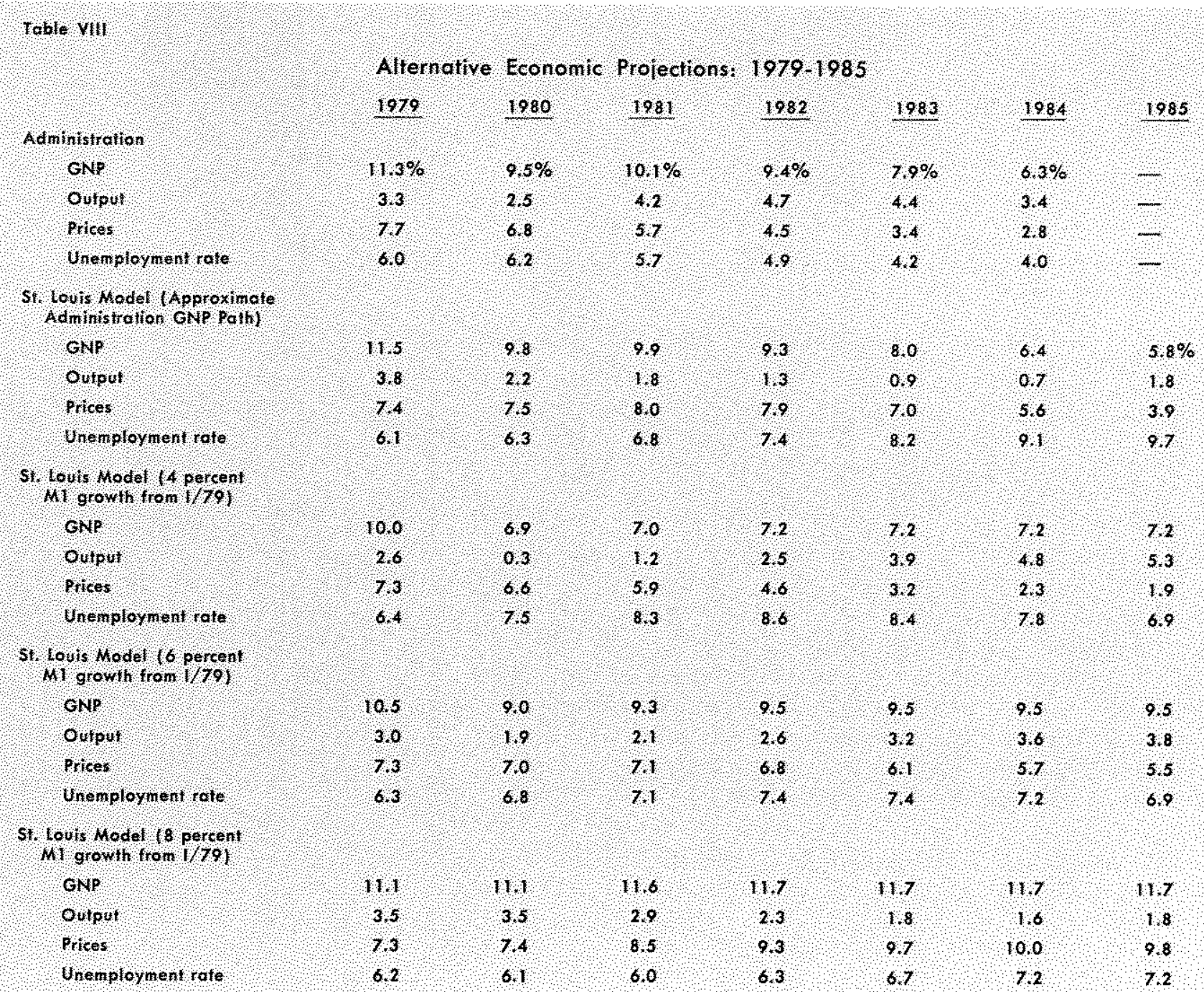

simultaneously. The Administration's economic plan focuses on the Federal budget and the wage-price guidelines. Monetary policy is discussed only generally. The potential impact of alternative courses of monetary expansion is not assessed.

The Administration presents projections for the long term, but does not develop a way to achieve the 1983 goals of the Humphrey-Hawkins Act. Its budget plan, however, when analyzed within the context of the Revenue Act of 1978, indicates that the goal of a balanced budget appears to be easily met. There is some question, however, whether the growth of
Federal spending is being reduced as rapidly as suggested in the Congressional policy statement.

The St. Louis model was used to simulate the Administration's plan. Using the GNP growth path projected by the Administration, achievement of the Humphrey-Hawkins inflation and unemployment targets does not appear feasible in the absence of new structurally-oriented programs. Furthermore, alternative courses of monetary expansion indicate that the goals of Humphrey-Hawkins will be difficult to achieve by 1983. The spirit of the Act would appear to be best met by aiming toward a moderate growth in the money stock. 